\title{
AKLIMATISASI TANAMAN ANGGREK PHALAENOPSIS PADA PENGGUNAAN JENIS MEDIA TANAM DAN KONSENTRASI PUPUK DAUN YANG BERBEDA
}

\author{
Acclimatization of Phalaenopsis Orchid on Type of Growth Media and Different \\ Concentration of Leaf Fertilizer
}

\author{
Erni Indriani*, Etik Wukir Tini, dan Heru Adi Djatmiko \\ Program Studi Agroteknologi, Fakultas Pertanian, Universitas Jenderal Soedirman \\ Jl. dr. Soeparno, Purwokerto
}

*Alamat Korespondensi: erniyehet8@gmail.com

\begin{abstract}
ABSTRAK
Penelitian ini bertujuan untuk mengetahui pengaruh jenis media tanam dan konsentrasi pupuk daun Farmer terhadap pertumbuhan vegetatif tanaman anggrek Phalaenopsis. Penelitian dilaksanakan di rumah plastik Desa Banjarsari Kulon, Kecamatan Sumbang, Kabupaten Banyumas dengan ketinggian tempat $\pm 250 \mathrm{~m}$ dpl. Desa Banjarsari Kulon berdasarkan letak astronomis berada pada 7,36 Lintang Selatan dan 109,24 Bujur Timur. Penelitian dilaksanakan dari bulan Desember 2017 sampai Maret 2018 dengan menggunakan Rancangan Acak Kelompok Lengkap dengan dua faktor perlakuan yaitu jenis media tanam (pakis, sabut kelapa dan akar kadaka) dan konsentrasi pupuk daun Farmer (0, 1, 2 dan $3 \mathrm{ml} / \mathrm{l}$ ). Variabel yang diamati adalah jumlah klorofil daun, luas daun, peningkatan jumlah daun, diameter batang, intensitas cahaya, suhu, kelembaban dan jumlah stomata. Data yang diperoleh dianalisis menggunakan uji F, apabila terdapat keragaman dilanjutkan Uji Jarak Berganda Duncan $(p=0,05)$. Hasil penelitian menunjukkan bahwa media tanam sabut kelapa menghasilkan jumlah stomata tanaman anggrek Phalaenopsis tertinggi yaitu sebesar 39,79 stomata $/ \mathrm{mm}^{2}$ dibandingkan media tanam akar kadaka $(35,77)$ dan pakis (34,96). Perlakuan konsentrasi pupuk daun Farmer $1 \mathrm{ml} / \mathrm{l}$ dan $2 \mathrm{ml} / \mathrm{l}$ menghasilkan peningkatan jumlah daun lebih banyak pada tanaman anggrek Phalaenopsis yaitu sebesar 1,20 dan 1,19 helai dibandingkan konsentrasi $0 \mathrm{ml} / \mathrm{l}$ (1,11 helai) dan $3 \mathrm{ml} / \mathrm{l}$ (1,12 helai).
\end{abstract}

Kata Kunci: Phalaenopsis, media tanam, pupuk daun

\begin{abstract}
The objective of this study was to know the effect of planting media and concentration of leaf fertilizer on the vegetative growth of Phalaenopsis orchid plant. The research was conducted in Screen house of Banjarsari Kulon Village, Sumbang Subdistrict, Banyumas regency, at the altitude of \pm 250 meter above sea level. Banjarsari Kulon village is based on astronomical location at $7.36^{\circ}$ South Latitude and 109,24 East Longitude. The research was conducted from December 2017 to March 2018 used a Randomized Complete Block Design with two treatment factors as type of planting media (fern, coconut husk and kadaka root) and concentration of leaf fertilizer (0, 1, 2 and $3 \mathrm{ml} / \mathrm{l}$ ). The observed variables were the number of leaf chlorophyll, leaf area, increasing number of leaves, stem diameter, light intensity, temperature, humidity and number of stomatal/0,144 $\mathrm{mm}^{2}$. The data obtained were analyzed using $F$ test, if there have significance different it will be followed by Duncan's Multiple Range Test of $p=0.05$. Result of the research showed that coconut husk had a higher number of Phalaenopsis orchid stomatal about 39.79 stomatal $/ \mathrm{mm}^{2}$ than kadaka root and fern about 35.77 and 34.96, respectively. Treatment of leaf fertilizer concentrations of 1 and $2 \mathrm{ml} / \mathrm{l}$ increased number of leaf on Phalaenopsis orchid about 1.20 and 1,19 compared to concentration of $0 \mathrm{ml} / \mathrm{l}(1.11)$ and $3 \mathrm{ml} / \mathrm{l}(1.12)$.
\end{abstract}

Key Words: Phalaenopsis, planting media, leaffertilizer.

\section{PENDAHULUAN}

Anggrek merupakan tanaman hias yang mempunyai nilai estetika tinggi.

Bentuk dan warna bunga serta karakteristik lainnya yang unik menjadikan daya tarik tersendiri sehingga banyak diminati oleh konsumen. Popularitas tanaman anggrek terus berkembang. Oleh karena itu untuk memenuhi kebutuhan pasar, maka upaya budidaya anggrek perlu dilakukan (Hani et al., 2014). 
Salah satu jenis anggrek yang populer adalah genus Phalaenopsis atau lebih dikenal dengan anggrek bulan. Kekhasan Phalaenopsis adalah bentuk bunganya lebih besar dengan warna yang bervariasi dan panjang mekar bunga yang lebih lama dibandingkan jenis anggrek lain. Keindahan Phalaenopsis tidak diikuti dengan ketersediaannya di alam. Keberadaan Phalaenopsis atau anggrek bulan semakin jarang, sehingga perlu dilakukan tindakan perbanyakan untuk melestarikannya (Jenny et al., 2009).

Budidaya anggrek bulan masih terdapat kendala, salah satunya adalah keberhasilan aklimatisasi bibit anggrek bulan dari botol ke dalam pot yang masih rendah. Salah satu alternatif untuk meningkatkan keberhasilan aklimatisasi anggrek adalah dengan menggunakan media tanam yang lain seperti: kadaka, pakis dan sabut kelapa dengan penambahan pupuk daun. Menurut Adi et al., (2014), yang menyatakan bahwa media tumbuh dan teknik penanaman merupakan faktor penting dalam proses aklimatisasi. Media yang digunakan harus mempermudah pertumbuhan akar dan menyediakan hara yang cukup bagi planlet. Teknik penanaman secara compot (community pot) yaitu dalam satu pot ditanami banyak tanaman anggrek dipercaya dapat mengurangi resiko kematian tanaman anggrek yang sedang diaklimatisasi, tetapi kemungkinan terjadi persaingan dalam mendapatkan unsur hara antara tanaman satu dengan yang lainnya.

Aklimatisasi merupakan tahap yang sangat penting dan menentukan keberhasilan perbanyakan tanaman anggrek. Aklimatisasi menjadi kendala dalam budidaya tanaman anggrek. Kendala yang dihadapi dalam tahap aklimatisasi dapat diatasi dengan penggunaan media tanam dan pemberian pupuk daun dengan konsentrasi yang tepat, sehingga perbanyakan anggrek dapat berhasil. Pupuk yang digunakan harus disesuaikan dengan kebutuhan tanaman, misalnya untuk pertumbuhan vegetatif tanaman maka pupuk yang digunakan harus mengandung unsur N. Nitrogen berfungsi untuk mendukung pertumbuhan tanaman pada fase vegetatif. Menurut Tirta (2006), yang menyatakan bahwa kandungan nitrogen yang tinggi menyebabkan pertumbuhan vegetatif (tinggi tanaman, diameter batang, jumlah daun, luas daun, jumlah tunas, jumlah akar dan panjang akar) lebih baik karena fungsi nitrogen dapat meningkatkan jumlah dan luas daun. Hal ini mengakibatkan meningkatnya fotosintat sehingga meningkatkan pertumbuhan organ-organ vegetatif. Unsur hara utama yang dibutuhkan anggrek dalam pertumbuhan vegetatifnya yaitu nitrogen. Nitrogen adalah unsur hara makro yang sangat diperlukan tanaman. Nitrogen adalah unsur makro primer yang merupakan 
komponen utama berbagai senyawa dalam tubuh tanaman. Tanaman yang tumbuh harus mengandung nitrogen dalam membentuk sel-sel baru. Penelitian ini bertujuan untuk mengetahui jenis media tanam dan konsentrasi pupuk daun terhadap pertumbuhan vegetatif tanaman anggrek Phalaenopsis

\section{METODE PENELITIAN}

Penelitian dilaksanakan di screen house Desa Banjarsari Kulon, Kecamatan Sumbang, Kabupaten Banyumas dengan ketinggian tempat $\pm 250 \mathrm{~m}$ dpl. Desa Banjarsari Kulon berdasarkan letak astronomis berada pada $7,36^{\circ}$ Lintang Selatan dan $109,24^{\circ}$ Bujur Timur. Suhu rata-rata pada pagi hari yaitu $27,45^{\circ} \mathrm{C}$, siang hari $31,32^{\circ} \mathrm{C}$ dan pada sore hari $27,03^{\circ} \mathrm{C}$. Kelembaban rata-rata pada pagi hari yaitu $90,58 \%$; siang hari $70,88 \%$ dan pada sore hari $77 \%$. Intensitas cahaya rata-rata pada pagi hari yaitu 769,65 lux; siang hari 1107,5 lux dan pada sore hari 439,58 lux. Penelitian dilaksanakan dari bulan Desember 2017 sampai Maret 2018 sekitar kurang lebih 16 minggu. Bahan penelitian yang digunakan meliputi bibit anggrek Phalaenopsis, pupuk daun Farmer, air, pakis, serat sabut kelapa, akar kadaka, fungisida Dithane M-45, cat kuku dan atonik 6,5 1. Alat yang digunakan dalam penelitian ini adalah alat tulis, Chlorophyll meter Soil Plant Analysis Development-502 plus, Jangka sorong Sellery 54-808, Thermohigro meter HTC-2, Mistar, Handsprayer Yoto 2 1, Gelas ukur Pyrex 10 ml, Digital Lux meter MS6612, Mikroskop, Pot dan Kertas milimeter blok Kerang Mas. Penelitian ini menggunakan Rancangan Acak Kelompok Lengkap dengan dua faktor perlakuan yaitu jenis media tanam dan konsentrasi pupuk daun Farmer. Faktor pertama yaitu jenis media tanam yang terdiri atas 3 taraf, antara lain pakis, sabut kelapa dan akar kadaka. Faktor kedua yaitu konsentrasi pupuk daun Farmer yang terdiri dari 4 taraf yaitu $0 \mathrm{ml} / 1,1 \mathrm{ml} / 1$, $2 \mathrm{ml} / 1$ dan $3 \mathrm{ml} / \mathrm{l}$. Penyiraman air dilakukan dua kali sehari pada pagi dan sore hari. Pemupukan dilakukan sekali dalam seminggu pada pagi atau sore hari dengan dosis $10 \mathrm{ml} / \mathrm{l}$ per tanaman. Penyemprotan atonik dan fungisida dilakukan sekali seminggu dengan dosis masing-masing yaitu $1 \mathrm{ml} / \mathrm{l}$ dan $3 \mathrm{gram} / \mathrm{l}$. Atonik berfungsi sebagai ZPT dan fungisida untuk mencegah tumbuhnya jamur.

Tahapan aklimatisasi dilakukan dengan menggunakan bahan genteng, kulit kayu, pakis dan akar kedakan yang sudah dibersihkan. Media yang sudah disiapkan tersebut dimasukan ke dalam compot dan disemprot dengan pestisida. Bibit anggrek kemudian dikeluarkan dari botol, dibersihkan lalu ditanam pada compot selama kurang lebih 5 minggu. Pemeliharaan compot dilakukan dengan 
penyiraman, dan aplikasi fungisida dan atonik. Pot individu dan media tanam disiapkan kemudian bibit anggrek dipindah dari compot ke pot individu. Penyiraman dilakukan dua kali sehari pada pagi dan sore hari. Penyemprotan fungisida dan atomic diberikan seminggu sekali. Pemupukan dilakukan seminggu sekali dengan konsentrasi pupuk $0,1,2$ dan $3 \mathrm{ml} / 1$ dengan volume pemberian setiap tanaman $10 \mathrm{ml}$.

Variabel yang diamati meliputi jumlah klorofil daun, luas daun, peningkatan jumlah daun, diameter batang, intensitas cahaya, suhu, kelembaban dan jumlah stomata. Data yang diperoleh dari hasil penelitian dianalisis dengan menggunakan analisis ragam (uji F) pada $p=5 \%$ dan apabila hasil analisis menunjukkan adanya pengaruh nyata, maka dilanjutkan dengan Uji DMRT (Duncan's Multiple Range Test) $p=5 \%$ untuk membandingkan pengaruh antar perlakuan.

\section{HASIL DAN PEMBAHASAN}

\section{A. Pengaruh Jenis Media Tanam terhadap Pertumbuhan Vegetatif Tanaman Anggrek Phalaenopsis}

Hasil analisis sidik ragam pada Tabel 1 menunjukkan bahwa penggunaan jenis media tanam yang berbeda tidak berpengaruh nyata terhadap jumlah klorofil. Hal tersebut diduga karena adanya faktor dari lingkungan yaitu suhu udara. Suhu udara yang ideal untuk anggrek Phalaenopsis yaitu di bawah $29^{\circ} \mathrm{C}$, sedangkan suhu udara rata-rata harian ketika penelitian pada siang hari mencapai $31,32^{\circ} \mathrm{C}$. Suhu udara mempengaruhi jumlah klorofil yang terdapat pada daun. Menurut Zakiyah et al. (2018), salah satu faktor lingkungan yang mempengaruhi kandungan klorofil yaitu suhu. Suhu merupakan salah satu faktor luar yang mempengaruhi pembentukan atau sintesa klorofil di dalam daun.

Perlakuan jenis media tanam tidak berpengaruh nyata terhadap luas daun tanaman anggrek Phalaenopsis. Menurut Sari (2011), luas daun merupakan suatu tanda tanaman melakukan pertumbuhan vegetatif. Pertumbuhan vegetatif sangat dipengaruhi oleh unsur $\mathrm{N}$ karena unsur $\mathrm{N}$ dapat memperbaiki pertumbuhan vegetatif tanaman. Hal ini sesuai dengan pernyataan Herliana (2018), bahwa tanaman anggrek dapat menyesuaikan diri dengan media apa saja tapi yang terpenting yaitu penyiraman dan pemupukannya tepat. Media untuk tanaman anggrek fungsi utamanya bukan untuk menyediakan unsur hara yang dibutuhkan tetapi lebih untuk tempat melekatnya akar, mempertahankan kelembaban dan menyimpan air. 
Tabel 1. Hasil analisis sidik ragam pengaruh penggunaan jenis media tanam dan konsentrasi pupuk daun yang berbeda terhadap beberapa karakter pertumbuhan vegetatif

\begin{tabular}{llccc}
\hline & \multicolumn{3}{c}{ Variabel Pengamatan } & \multicolumn{3}{c}{ Perlakuan } \\
\cline { 3 - 5 } No. & & $\begin{array}{c}\text { Jenis Media } \\
\text { Tanam }(\mathrm{M})\end{array}$ & $\begin{array}{c}\text { Konsentrasi } \\
\text { pupuk daun }(\mathrm{K})\end{array}$ & $\mathrm{M} \times \mathrm{K}$ \\
\hline 1. & Jumlah klorofil (unit SPAD) & tn & tn & tn \\
2. & Luas daun $\left(\mathrm{cm}^{2}\right)$ & tn & tn & tn \\
3. & Peningkatan jumlah daun (helai) & tn & n & tn \\
4. & Diameter batang $(\mathrm{cm})$ & tn & tn & tn \\
5. & Jumlah stomata $\left(\mathrm{JS} / \mathrm{mm}^{2}\right)$ & $\mathrm{n}$ & tn & tn \\
\hline
\end{tabular}

Keterangan $: \mathrm{n}=$ nyata dan $\mathrm{n}=$ tidak nyata pada $p=0.05$.

Tabel 2. Pengaruh penggunaan jenis media tanam terhadap pertumbuhan vegetatif tanaman anggrek Phalaenopsis.

\begin{tabular}{lccccc}
\hline Jenis Media & $\begin{array}{c}\text { Jumlah } \\
\text { klorofil } \\
\text { (unit) }\end{array}$ & $\begin{array}{c}\text { Luas daun } \\
\left(\mathrm{cm}^{2}\right)\end{array}$ & $\begin{array}{c}\text { Peningkatan } \\
\text { jumlah daun } \\
\text { (helai) }\end{array}$ & $\begin{array}{c}\text { Diameter } \\
\text { batang }(\mathrm{cm})\end{array}$ & $\begin{array}{c}\text { Jumlah } \\
\text { stomata } \\
\left(\mathrm{mm}^{2}\right)\end{array}$ \\
\hline Pakis & 1,68 & 1,33 & 1,15 & 1,65 & $34,96 \mathrm{~b}$ \\
Sabut kelapa & 1,52 & 1,30 & 1,19 & 1,67 & $39,79 \mathrm{a}$ \\
Akar kadaka & 1,60 & 1,34 & 1,12 & 1,66 & $35,77 \mathrm{~b}$ \\
\hline
\end{tabular}

Keterangan: Angka yang diikuti huruf yang berbeda pada kolom yang sama menunjukkan hasil yang berbeda nyata pada Uji DMRT $p=0,05$.

Hasil analisis sidik ragam pada Tabel 1 menunjukkan bahwa penggunaan jenis media tanam yang berbeda tidak berpengaruh nyata terhadap peningkatan jumlah daun. Perhitungan jumlah daun dihitung dari daun terbawah yang masih hijau dan sehat hingga daun teratas tanaman. Kemunculan daun baru, dihitung sebagai satu daun jika telah tumbuh dan berkembang menjadi daun muda (Yasmin et al., 2018). Menurut Febrizawati et al. (2014), pembentukan daun berawal dari pembelahan sel yang terjadi di dekat apeks tajuk yang kemudian akan membentuk primordial daun. Terjadinya penambahan jumlah daun suatu tanaman disebabkan oleh peristiwa pembelahan dan pepanjangan sel yang didominasi di bagian ujung pucuk.
Menurut (Sukma dan Setiawan, 2010), pertambahan jumlah daun yang relatif kecil disebabkan sedikitnya jumlah anakan baru yang muncul. Pertambahan jumlah daun berkaitan dengan pertambahan jumlah anakan, karena anakan yang sudah mencapai tinggi maksimal tidak akan mempunyai daun baru. Penurunan jumlah daun di beberapa minggu pengamatan disebabkan adanya daun yang menguning dan gugur, sehingga mengurangi jumlah daun yang diamati.

Jenis media tanam tidak berpengaruh nyata terhadap diameter batang tanaman anggrek Phalaenopsis. Menurut Febrizawati et al. (2014), diameter batang merupakan proses pertumbuhan dari hasil pembesaran dan diferensiasi. Hal ini 
dipengaruhi oleh penyerapan unsur hara pada tanaman sehingga hasil fotosintesis dapat ditranslokasikan tanaman ke bagian batang dimana sangat berhubungan erat dengan cadangan makanan. Tersedianya unsur hara dalam jumlah yang cukup dan seimbang untuk pertumbuhan tanaman, menyebabkan proses pembelahan, pembesaran dan pemanjangan sel akan berlangsung cepat yang mengakibatkan beberapa organ tanaman tumbuh cepat.

Hasil analisis sidik ragam menunjukkan bahwa penggunaan jenis media tanam berpengaruh nyata terhadap jumlah stomata. Tabel 2 menunjukkan bahwa media tanam sabut kelapa menghasilkan jumlah stomata tertinggi yaitu sebesar 39,79 stomata $/ \mathrm{mm}^{2}$ dibandingkan dengan media tanam lainnya yaitu akar kadaka sebesar 35,77 stomata $/ \mathrm{mm}^{2}$ dan hasil terendah pada media tanam pakis sebesar 34,96 stomata/ $/ \mathrm{mm}^{2}$. Menurut Adi et al. (2014), serabut kelapa merupakan media yang mampu mengikat air dan banyak mengandung unsur kalium yang dapat mempengaruhi sistem enzim pada proses fotosintesis dan translokasi karbohidrat serta mengatur membuka dan menutupnya stomata. Menurut Andalasari et al. (2014), yang menyatakan bahwa cocochip merupakan limbah kelapa berupa sabut kelapa yang dipotong kecil. Sabut kelapa cukup mudah didapat dan murah harganya, sehingga berpotensi untuk digunakan sebagai alternatif media tanam anggrek. Media yang terbaik dalam tahap aklimatisasi pada anggrek adalah sabut kelapa yang memiliki kemampuan menyimpan air dan hara dengan baik.

\section{B. Pengaruh Konsentrasi Pupuk Daun terhadap Pertumbuhan Vegetatif Tanaman Anggrek Phalaenopsis}

Hasil analisis sidik ragam pada Tabel 1 menunjukkan bahwa perlakuan konsentrasi pupuk daun tidak berpengaruh nyata terhadap jumlah klorofil. Hal tersebut diduga karena adanya faktor dari lingkungan yaitu suhu udara. Suhu udara yang ideal untuk anggrek Phalaenopsis yaitu di bawah $29^{\circ} \mathrm{C}$, sedangkan suhu udara rata-rata harian ketika penelitian pada siang hari mencapai $31,32^{\circ} \mathrm{C}$. Suhu udara mempengaruhi jumlah klorofil yang terdapat pada daun. Menurut Zakiyah et al. (2018), salah satu faktor lingkungan yang mempengaruhi kandungan klorofil yaitu suhu. Suhu merupakan salah satu faktor luar yang mempengaruhi pembentukan atau sintesa klorofil di dalam daun.

Perlakuan konsentrasi pupuk daun tidak berpengaruh nyata terhadap luas daun tanaman anggrek Phalaenopsis. Menurut Sari et al. (2011), pengaruh konsentrasi pupuk daun terhadap pertumbuhan vegetatif tanaman tidak berpengaruh nyata terhadap luas daun. Hal ini diduga disebabkan karena 
pertumbuhan vegetatif anggrek yang tergolong lambat menyebabkan tidak adanya perbedaan luas daun tanaman anggrek pada perlakuan pemupukan. Sepanjang masa vegetatif, meliputi akar, daun dan batang merupakan daerah-daerah pemanfaatan yang kompetitif dalam pembagian hasil fotosintesis. Hal ini juga disebabkan karena kondisi lingkungan dan juga pengaruh perlakuan pemupukan, selain itu juga dikarenakan unsur hara yang diberikan belum bisa diserap secara optimal oleh akar, sehingga proses pertumbuhan terhambat. Luas daun merupakan suatu tanda tanaman melakukan pertumbuhan vegetatif. Pertumbuhan vegetatif sangat dipengaruhi oleh unsur $\mathrm{N}$ karena unsur $\mathrm{N}$ dapat memperbaiki pertumbuhan vegetatif tanaman.

Hasil analisis sidik ragam pada Tabel 1 menunjukkan bahwa konsentrasi pupuk daun berpengaruh nyata terhadap peningkatan jumlah daun. Gambar 1 menunjukkan bahwa konsentrasi pupuk daun $1 \mathrm{ml} / \mathrm{l}$ dan $2 \mathrm{ml} / \mathrm{l}$ menghasilkan peningkatan jumlah daun tinggi yaitu sebesar 1,20 dan 1,19 helai, diikuti $3 \mathrm{ml} / 1$ dan yang terendah kontrol $0 \mathrm{ml} / \mathrm{l}$ yang masing-masing menghasilkan peningkatan jumlah daun sebesar 1,12 dan 1,11 helai.

Apabila dicari konsentrasi pupuk daun yang paling optimal di luar perlakuan konsentrasi yang dilakukan atau dicoba yaitu konsentrasi $\quad 1,5 \quad \mathrm{ml} / \mathrm{l} \quad$ yang menghasilkan peningkatan jumlah daun sebesar 1,21 helai. Pengaruh konsentrasi pupuk daun terhadap jumlah daun tanaman anggrek Phalaenopsis yaitu sebesar $98,77 \%$. Hal ini sesuai dengan pernyataan Andriyani dan Yanti (2006), yang menyatakan bahwa hal yang harus diperhatikan dalam pemberian pupuk melalui daun agar efisien yaitu konsentrasinya harus sesuai. Pemberian pupuk melalui daun harus diberikan dalam konsentrasi yang tidak terlalu banyak, tetapi pemberiannya harus sering dilakukan dengan interval waktu yang sesuai.

Menurut Putra et al. (2016), peningkatan jumlah daun adalah salah satu indikator tanaman mencapai tahap dewasa. Jumlah daun yang meningkat maka tanaman mampu melakukan fotosintesis secara maksimal untuk mendukung proses transisinya menuju fase reproduktif. Perlakuan konsentrasi pupuk daun tidak berpengaruh nyata terhadap diameter batang tanaman anggrek Phalaenopsis.

Menurut Supriyadi dan Jaenudin (2013), menyatakan bahwa dengan meningkatkan serapan unsur hara oleh tanaman dapat memperbaiki pertumbuhan tanaman, seperti halnya diameter batang. 
Tabel 3. Pengaruh konsentrasi pupuk daun terhadap pertumbuhan vegetatif tanaman anggrek Phalaenopsis.

\begin{tabular}{cccccc}
\hline $\begin{array}{c}\text { Konserntrasi } \\
\text { pupuk daun } \\
(\mathrm{ml} / \mathrm{l})\end{array}$ & $\begin{array}{c}\text { Jumlah } \\
\text { klorofil } \\
\text { (unit) }\end{array}$ & $\begin{array}{c}\text { Luas daun } \\
\left(\mathrm{cm}^{2}\right)\end{array}$ & $\begin{array}{c}\text { Peningkatan } \\
\text { jumlah daun } \\
\text { (helai) }\end{array}$ & $\begin{array}{c}\text { Diameter } \\
\text { batang }(\mathrm{cm})\end{array}$ & $\begin{array}{c}\text { Jumlah } \\
\text { stomata } \\
\left(\mathrm{mm}^{2}\right)\end{array}$ \\
\hline 0 & 1,59 & 1,31 & $1,11 \mathrm{~b}$ & 1,62 & 36,83 \\
1 & 1,52 & 1,30 & $1,20 \mathrm{a}$ & 1,69 & 36,87 \\
2 & 1,65 & 1,35 & $1,19 \mathrm{a}$ & 1,68 & 35,62 \\
3 & 1,64 & 1,33 & $1,12 \mathrm{~b}$ & 1,64 & 38,05 \\
\hline
\end{tabular}

Keterangan: Angka yang diikuti huruf yang berbeda pada kolom yang sama menunjukkan hasil yang berbeda nyata pada Uji $D M R T p=0,05$.

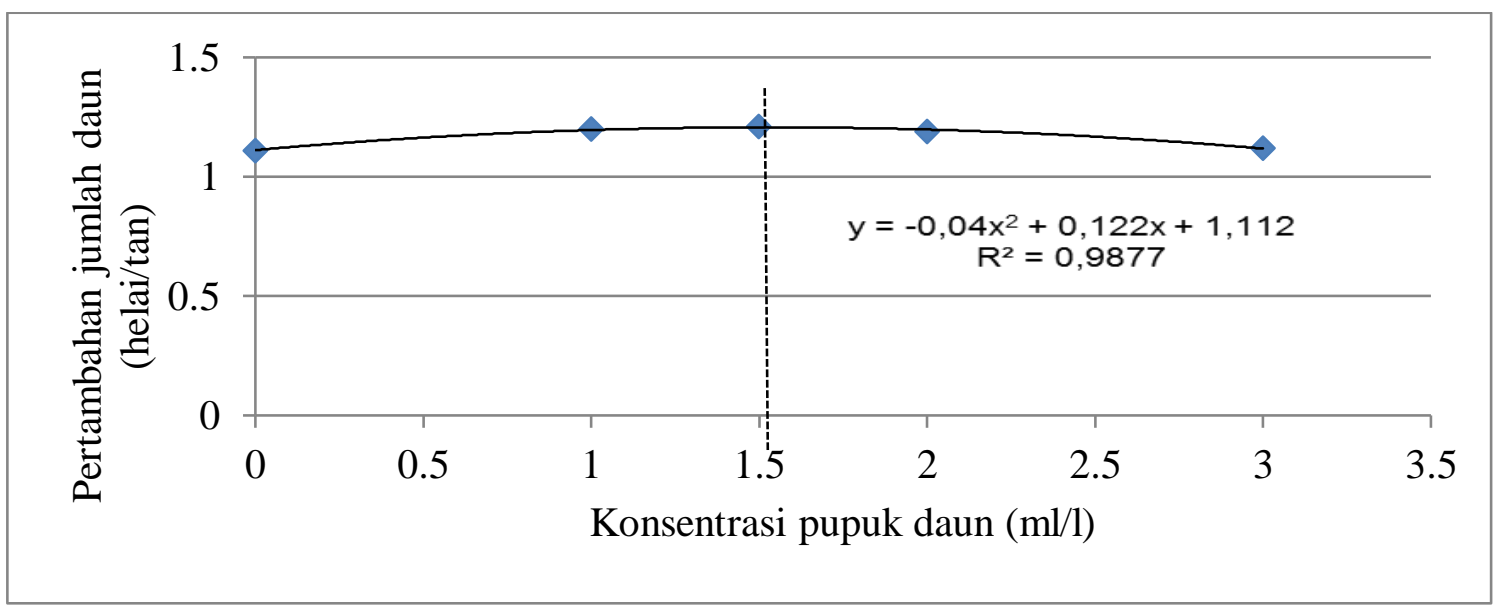

Gambar 1. Hubungan antara konsentrasi pupuk daun dan pertambahan jumlah daun tanaman anggrek Phalaenopsis.

Salah satu cara untuk meningkatkan unsur hara tanaman yaitu dengan pemupukan, tetapi apabila pemupukan yang dilakukan tidak dapat diserap oleh tanaman dengan baik maka unsur hara yang dibutuhkan tanaman untuk pertumbuhan diameter batang tidak dapat terpenuhi. Faktor luar yang mempengaruhi penyerapan unsur hara oleh tanaman yaitu suhu, kelembaban, intensitas cahaya dan air. Menurut Hairuddin et al. (2018), menyatakan bahwa dengan penyerapan hara tanaman dapat memenuhi siklus hidupnya dan sebaliknya. Kegiatan metabolisme tanaman akan terganggu apabila ketersediaan hara yang berkurang atau tidak ada. Pemupukan sangat berpengaruh bagi pertumbuhan tanaman terlebih bila media tanam tergolong miskin hara. Pemupukan yang tidak tepat, baik dari segi jenis, jumlah, cara pemberian, dan waktu pemberian dapat mempengaruhi proses pertumbuhan dan perkembangan tanaman.

Hasil analisis sidik ragam menunjukkan bahwa konsentrasi pupuk daun tidak berpengaruh nyata terhadap jumlah stomata. Menurut Priyadi dan Hendriyani (2016), densitas stomata (jumlah per satuan luas daun) merupakan salah satu karakter penting untuk diketahui. 
Karakter ini dikendalikan secara genetis dan dipengaruhi oleh faktor lingkungan.

Faktor lingkungan yang mempengaruhi jumlah stomata salah satunya adalah kelembaban. Kelembaban nisbi (RH) yang dibutuhkan tanaman anggrek rata-rata yaitu sebesar $70-80 \%$, tetapi pada saat penelitian kelembaban rata-rata pada pagi hari mencapai 90,58 \%. Menurut Perkasa et al. (2017), jumlah stomata dipengaruhi oleh faktor lingkungan diantaranya yaitu intensitas cahaya, temperatur, kelembaban dan konsentrasi $\mathrm{CO}_{2}$ di udara.

\section{KESIMPULAN}

1. Media tanam sabut kelapa hanya mampu meningkatkan jumlah stomata tanaman anggrek Phalaenopsis yaitu sebesar $\quad 39,79 \quad$ stomata/ $\mathrm{mm}^{2}$ dibandingkan media tanam akar kadaka dan pakis yang masing-masing menghasilkan jumlah stomata sebesar 35,77 dan 34,96 stomata/ $\mathrm{mm}^{2}$.

2. Pupuk daun Farmer $1 \mathrm{ml} / \mathrm{l}$ dan $2 \mathrm{ml} / 1$ menghasilkan peningkatan jumlah daun banyak pada tanaman anggrek Phalaenopsis yaitu sebesar 1,20 dan 1,19 helai dibandingkan 0 dan $3 \mathrm{ml} / \mathrm{l}$ yang masing-masing menghasilkan jumlah daun sebesar 1,11 ; dan 1,12 helai.

\section{DAFTAR PUSTAKA}

Adi, N.K.A.P., I. A. Astarini, dan Ni P. A. Astiti. 2014. Aklimatisasi Anggrek Hitam (Coelogyne pandurata Lindl.) Hasil Perbanyakan In Vitro Pada Media Berbeda. Jurnal Simbiosis, 2(2): $203-214$.

Andalasari, T.D., Yafisham, dan Nuraini. 2014. Respon Pertumbuhan Anggrek Dendrobium Terhadap Jenis Media Tanam dan Pupuk Daun. Jurnal Penelitian Pertanian Terapan, 14(1):76-82.

Andriyani dan L. Yanti. 2006. Pengaruh Konsentrasi dan Frekuensi Penyemprotan Pupuk Daun Terhadap Pertumbuhan Plantlet Anggrek Dendrobium (Dendrobium Jade Gold) Pada Tahap Aklimatisasi. Jurnal Agronomi, 10(1): 51 - 54.

Febrizawati. Murniati, S. Yoseva. 2014. Pengaruh Komposisi Media Tanam dengan Konsentrasi Pupuk Cair terhadap Pertumbuhan Tanaman Anggrek Dendrobium (Dendrobium sp.). Jom Faperta, 1(2): 1 - 12.

Hairuddin, R., M. Yamin dan A. Riadi. 2018. Respon Pertumbuhan Tanaman Anggrek Dendrobium sp. Pada Beberapa Konsentrasi Air Cucian Ikan Bandeng dan Air Cucian Beras Secara In Vivo. Jurnal Perbal. 6(2): 23 - 29.

Hani, A., T. S. Widyaningsih dan R. U. Damayanti. 2014. Potensi dan Pengembangan Jenis-Jenis Tanaman Anggrek dan Obat-Obatan di Jalur Wisata Loop-Trail CikanikiCitalahab Taman Nasional Gunung Halimun-Salak. Jurnal Ilmu Kehutanan, 8(1): $42-49$.

Herliana, O., E. Rokhminarsi, S. Mardini, dan M. Jannah. 2018. Pengaruh Jenis Media Tanam dan Aplikasi Pupuk Hayati Mikoriza Terhadap Pertumbuhan, Pembungaan dan 
Infeksi Mikoriza Pada Tanaman Anggrek Dendrobium sp. Jurnal Kultivasi, 17(1): 550 - 557.

Jenny, J., Rondonuwu dan D.D. Pioh. 2009. Kebutuhan Hara Tanaman Hias Anggrek. Soil Environment, 7(1): 73 -79 .

Perkasa, A.Y., T. Siswanto, F. Shintarika, T. dan G. Aji. 2017. Studi Identifikasi Stomata Pada Kelompok Tanaman C3, C4 dan CAM. Jurnal Pertanian Presisi, 1(1):59 - 72 .

Priyadi, A. dan E. Hendriyani. 2016. Karakter Morfo-Fisiologi Daun Tiga Jenis Plantlet Anggrek Pada Tahap Aklimatisasi. Jurnal Hortikultura, 26(2): 143 - 152.

Putra, R.R., I. S. Mercuriani dan E. Semiarti. 2016. Pengaruh Cahaya dan Temperatur Terhadap Pertumbuhan Tunas dan Profil Protein Tanaman Anggrek Phalaenopsis amabilis Transgenik Pembawa Gen Ubipro: PaFT. Bioeksperimen, 2(2): 79 - 90.

Sari, E.R., C. Udayana dan T. Wardiyati. 2011. Pengaruh Volume Pemberian Air dan Konsentrasi Pupuk Daun Terhadap Pertumbuhan Vegetatif Tanaman Anggrek Dendrobium undulatum. Buana sains, 11(1): 77 82.
Sukma, D. dan A. Setiawan. 2010. Pengaruh Waktu dan Frekuensi Aplikasi Pupuk Daun Terhadap Pertumbuhan dan Pembungaan Anggrek Dendrobium Tong Chai Gold. Jurnal Hort. Indonesia, 1(2): $97-104$.

Supriyadi, E. dan A. Jaenudin. 2013. Pengaruh Cendawan Mikoriza Arbuskular (CMA) dan Pupuk Fosfat Serapan P, Pertumbuhan dan Hasil Jagung (Zea mays L.) Kultivar DK3. Jurnal Agroswagati, 1(2): 101 -112 .

Tirta, I.G.. 2006. Pengaruh Beberapa Jenis Media Tanam dan Pupuk Daun terhadap Pertumbuhan Vegetatif Anggrek Jamrud (Dendrobium macrophyllum A. Rich.). Biodiversitas. 7(1): $81-84$.

Yasmin, Z.F., S.I. Aisyah dan D Sukma. 2018. Pembibitan Kultur Jaringan Hingga Pembesaran Anggrek Phalaenopsis di Hasanudin Orchids, Jawa Timur. Bul. Agrohorti. 6(3): $411-420$.

Zakiyah, M., Manurung, T.F. Reine dan S. Wulandari. 2018. Kandungan Klorofil Daun Pada Empat Jenis Pohon di Arboretum Sylva Indonesia PC. Universitas Tanjungpura. Jurnal Hutan Lestari, 6(1): 48 - 55. 